\title{
A Novel High-performance Liquid Chromatography Method with Fluorescence Detection for the Quantification of Roflumilast in Tablet Formulations
}

\section{Roflumilastın Tablet Formülasyonlarda Miktar Tayini için Yeni Bir Floresans Dedeksiyonlu Yüksek Performanslı Sıvı Kromatografisi Yöntemi}

\section{(1) Ulvi MEHDIZADE, iD Pelin KÖSEOĞLU YILMAZ}

İstanbul Üniversitesi Eczacılık Fakültesi, Analitik Kimya Anabilim Dalı, İstanbul, Türkiye

\begin{abstract}
Objective: This study aims to develop and validate a novel highperformance liquid chromatography method with fluorescence detection for quantifying roflumilast in tablet formulations.

Methods: Separations were achieved by a C18 analytical column $(250 \times 4.6 \mathrm{~mm}, 5 \mu \mathrm{m})$ at $40{ }^{\circ} \mathrm{C}$. Isocratic elution accompanied by a mobile phase comprising $20 \%$ aqueous o-phosphoric acid solution $(0.08 \%)$ and $80 \%$ methanol was applied. The excitation and the emission wavelengths were 290 and $380 \mathrm{~nm}$, respectively.

Results: The linear range was $1.25-10.00 \mu \mathrm{g} / \mathrm{mL}$. Irbesartan was used as the internal standard. The limits of detection and quantification were $0.07 \mu \mathrm{g} / \mathrm{mL}$ and $0.22 \mu \mathrm{g} / \mathrm{mL}$, respectively. The precision and accuracy of the method was determined at the concentrations of $1.25,5.00$ and $10.00 \mu \mathrm{g} / \mathrm{mL}$. The recovery percentage was calculated by the tablet solutions spiked at low, middle and high concentrations. The robustness of the method was tested in terms of flow rate, mobile phase composition and column temperature.

Conclusion: The proposed method was successfully applied for determining roflumilast in tablet formulations with a high precision and accuracy.
\end{abstract}

Keywords: Fluorescence, HPLC, method development, roflumilast, validation

\section{ÖZ}

Amaç: Bu çalışmada roflumilastın tablet formülasyonlarda miktar tayini için yeni bir floresans dedektörlü yüksek performanslı sıvı kromatografisi yönteminin geliştirilmesi amaçlandı.

Yöntemler: Ayırma işlemleri $40{ }^{\circ} \mathrm{C}$ 'de bir C18 analitik kolon (250x4,6 mm, $5 \mu \mathrm{m})$ ile gerçekleştirildi. Mobil faz olarak \%20 sulu o-fosforik asit çözeltisi $(\% 0,08)$ ve $\% 80$ metanol içeren bir sistem kullanıldı ve izokratik elüsyon uygulandı. Eksitasyon ve emisyon dalga boyları sırasıyla 290 ve $380 \mathrm{~nm}$ olarak belirlendi.

Bulgular: Doğrusal aralık 1,25-10,00 $\mu \mathrm{g} / \mathrm{mL}$ olarak tespit edildi. İç standart olarak irbesartan kullanıldı. Gözlenebilme ve tayin sınırları sırası ile $0,07 \mu \mathrm{g} / \mathrm{mL}$ ve $0,22 \mu \mathrm{g} / \mathrm{mL}$ idi. Yöntemin kesinlik ve doğruluğu $1,25,5,00$ ve $10,00 \mu \mathrm{g} / \mathrm{mL}$ konsantrasyonlarındaki standart çözeltiler ile belirlendi. Yüzde geri kazanım düşük, orta ve yüksek konsantrasyonlarda standart eklenen tablet çözeltilerinin analiz sonuçları ile hesaplandı. Yöntemin sağlamlığı akış hızı, mobil faz bileşimi ve kolon sıcaklığı parametreleri ile incelendi.

Sonuç: Önerilen metot roflumilastın tablet formülasyonlarda yüksek kesinlik ve doğruluk ile tayini için başarılı bir şekilde uyguland.

Anahtar Sözcükler: Floresans, HPLC, metot geliştirme, roflumilast, validasyon
Address for Correspondence: Pelin KÖSEOČLU YILMAZ, İstanbul Üniversitesi Eczacılık Fakültesi, Analitik Kimya Anabilim Dalı, İstanbul, Türkiye

E-mail: pelink@istanbul.edu.tr ORCID ID: orcid.org/0000-0002-9871-1710

Cite this article as: Mehdizade U, Köseoğlu Yılmaz P. A Novel High-performance Liquid Chromatography Method with Fluorescence Detection for the Quantification of Roflumilast in Tablet Formulations. Bezmialem Science 2021;9(2):253-8.

${ }^{0}$ Copyright 2021 by the Bezmiâlem Vakıf University

Bezmiâlem Science published by Galenos Publishing House.
Received: 21.03 .2020

Accepted: 24.04.2020 


\section{Introduction}

Chronic obstructive pulmonary disease (COPD) is a health issue causing chronic airflow obstruction that is not fully reversible $(1,2)$. Its risk factors include deficiency of alpha- 1 antitrypsin, cigarette smoking, occupational chemical exposure and air pollution with cigarette smoking being the most common one. Pharmacological treatments are successful in reducing symptoms and exacerbations while improving the health status and increasing the exercise tolerance (3).

Roflumilast (RFL) (3-(cyclopropylmethoxy)-N-(3,5-dichloro-4pyridyl)-4-(difluoromethoxy) benzamide) (Figure 1) is currently an approved selective phosphodiesterase-4 (PDE-4) inhibitor for treating COPD. RFL is available in $500 \mu \mathrm{g}$ tablets, and the recommended dose is 1 tablet/day. The absolute bioavailability of RFL is $79 \%$ following oral administration (4). It is then metabolized by cytochrome p450 (CYP) 3A4 and 1A2 isozymes to its active metabolite-RFL $\mathrm{N}$-oxide (5). Daxas ${ }^{\circ}$, with the active pharmaceutical ingredient of RFL, was approved in the European Union in June 2010. It further received Food and Drug Administration's (FDA) approval in the USA in March 2011 (6).

RFL is not an official drug in the British Pharmacopoeia, European Pharmacopoeia and United States Pharmacopoeia yet and has no official monograph $(7,8)$. In contrast, several studies have described the analytical methods for quantifying RFL in pharmaceutical forms in the presence or absence of degradation products (DP). High-performance liquid chromatography (HPLC) is one of the commonly used techniques to achieve this purpose. A previous study developed and validated a reverse phase (RP)-HPLC method with ultraviolet (UV) detection for determining RFL in formulations (6). Belal et al. (7) developed a stability-indicating HPLC method with a diode-array detector (DAD) for determining RFL and achieved the application of the proposed method for analysing the tablet formulation. Pinheiro et al. (8) developed and validated a RP-HPLC method with DAD and corona-charged aerosol detector in line for RFL and its DPs and successfully separated RFL from six DPs. Tan (9) developed and validated an HPLC method for quantifying RFL in the presence of its DPs and related substances to control the drug's

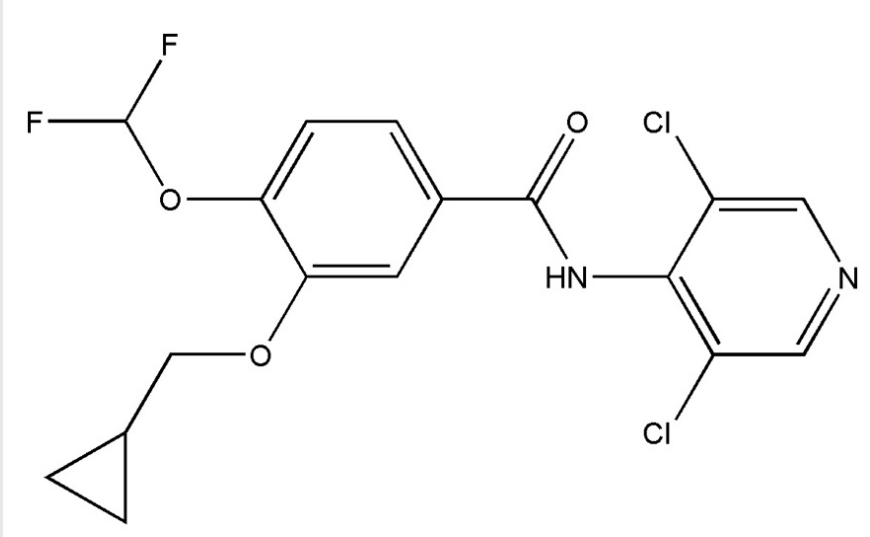

Figure 1. Chemical structure of roflumilast purity. Also, a validated stability-indicating high-performance thin-layer chromatography method was applied for determining RFL in tablets (10). Besides chromatographic methods, a different research developed and validated a UV-visible spectrophotometric method for the quantitative determination of RFL in tablet formulation (11). Atmaca and Süslü (12) validated a first-order derivative UV spectrophotometric method for determining RFL in pharmaceutical formulations. Also, Güray (13) reported a new and validated capillary electrophoresis method with UV detection to successfully determine RFL in tablets.

HPLC with fluorescence detection (FD) may be an alternative for analysing RFL with a considerably higher selectivity than UV detection. The objective of this study is to develop and validate a sensitive and simple method for determining RFL in tablet formulations by HPLC-FD without a derivatisation reaction. To the best of knowledge, our study could be the first report on the determination of RFL by HPLC-FD.

\section{Methods}

\section{Chemicals and Solutions}

The standards of RFL and irbesartan (IRB) were kindly provided by Abdi İbrahim Pharmaceuticals (İstanbul, Turkey). The HPLC grade methanol $(\mathrm{MeOH})$ was purchased from Isolab (Eschau, Germany) and o-phosphoric acid was purchased from Merck (Darmstadt, Germany). The commercial tablets of DAXAS containing $500 \mu \mathrm{g}$ of RFL were analysed.

The stock solutions of RFL and IRB at $100.00 \mu \mathrm{g} / \mathrm{mL}$ were prepared with HPLC grade $\mathrm{MeOH}$ and kept at $4{ }^{\circ} \mathrm{C}$ protected from daylight. The standard solutions were prepared daily by the dilution of the stock solutions with the mobile phase to desired concentrations.

For the preparation of the tablet solution, ten DAXAS $^{\circ}$ tablets were weighed individually and the average weight of tablet was calculated $(0.2660 \mathrm{~g})$. Then, the tablets were grounded and an amount of powder equal to the average tablet weight was transferred into a $100 \mathrm{~mL}$ volumetric flask. In total, $60 \mathrm{~mL}$ of $\mathrm{MeOH}$ and $2.50 \mathrm{~mL}$ of IRB stock solution were added in the flask and the solution was kept in an ultrasonic bath for 30 minutes. Later, the volume was adjusted to $100 \mathrm{~mL}$ with $\mathrm{MeOH}$. The final concentrations of RFL and IRB were $5.00 \mu \mathrm{g} / \mathrm{mL}$ and $2.50 \mu \mathrm{g} / \mathrm{mL}$, respectively. The spiked tablet solutions were prepared by the addition of $1.00,2.50$ and $5.00 \mathrm{~mL}$ of the stock RFL solution before fixing the volume to $100 \mathrm{~mL}$.

Appropriate volumes of the stock IRB solution were added to all the solutions for obtaining a final concentration of $2.50 \mu \mathrm{g} / \mathrm{mL}$. All the solutions were filtered through a $0.45-\mu \mathrm{m}$ filter before injection into the HPLC-FD system.

\section{Instrument and Analytical Conditions}

The analyses were performed by a Shimadzu LC20AT HPLC system with FD (RF20A) (Shimadzu, Kyoto, Japan). The separation was achieved using a GL Sciences Inertsil ODS-3 
analytical column (C18, 4.6x250 mm, particle size of $5.0 \mu \mathrm{m})$ (GL Sciences Inc., Tokyo, Japan). The data were analysed by the LabSolutions software (version 1.25).

Isocratic elution was applied with a mobile phase system comprising 20\% o-phosphoric acid solution (0.08\%, pH: 2.3) and $80 \%$ methanol. The excitation and the emission wavelengths were 290 and $380 \mathrm{~nm}$, respectively. The flow rate was set to 1.0 $\mathrm{mL} / \mathrm{min}$, and the injection volume was $20 \mu \mathrm{L}$. The column temperature was adjusted to $40{ }^{\circ} \mathrm{C}$.

\section{Quantification}

RFL was identified by comparing the retention time with the one of its standards. The quantification was performed by the internal standard method using IRB as the internal standard.

\section{Validation}

The developed method was validated in terms of linearity, limit of detection (LOD), limit of quantitation (LOQ), precision, accuracy and robustness.

\section{Linearity}

The linearity was determined by a seven-point calibration curve for RFL. The calibration curve was plotted as the analyte's peak area/internal standard's peak area versus concentration with the data of triplicate analyses/day performed in three different days. Calibration equation and $r^{2}$ value were calculated using the linear regression analysis based on the least-squares method.

\section{Limits of Detection and Quantitation (LOD and LOQ)}

LOD and LOQ were determined as 3.3 and 10 times of the ratio of the standard deviation of the calibration curve to the slope of the calibration curve, respectively.

\section{Precision and Accuracy}

Precision was examined as repeatability (intraday) and intermediate precision (interday) with standard solutions at $1.25,5.00$ and $10.00 \mu \mathrm{g} / \mathrm{mL}$ in terms of relative standard deviation relative standard deviation (RSD\%). Repeatability was determined by the data of triplicate injections consecutively in one day. Intermediate precision values were calculated in triplicate analytical runs in three different days. Accuracy was determined as the relative mean error (\%) with standard solutions at 1.25, 5.00 and $10.00 \mu \mathrm{g} / \mathrm{mL}$ in triplicate analyses.

The original $(5.00 \mu \mathrm{g} / \mathrm{mL}$ ) and spiked (at 1.00, 2.50 and 5.00 $\mu \mathrm{g} / \mathrm{mL}$ ) tablet solutions were analysed in triplicates. RSD (\%), RME (\%) and recovery (\%) values were calculated.

\section{Specificity}

An injection of only the mobile phase as the sample was performed to check the specificity of the method.

\section{Robustness}

The robustness of the method was checked by considering the parameters of the flow rate, the mobile phase composition and the column temperature. The flow rate was varied \pm 0.1 whereas the others were varied \pm 1 of the original values and and the RFL concentration of the tablet solution was calculated under these conditions. The results were obtained as RME\%.

\section{Results}

\section{Selection of HPLC Conditions}

Several studies were performed using different types of mobile phase systems comprising mixtures of water, methanol, acetonitrile, o-phosphoric acid and formic acid with various proportions and gradient and isocratic elution. A mobile phase comprising 20\% o-phosphoric acid solution (0.08\%) and 80\% methanol with isocratic elution was selected after considering the system suitability parameters (Table 1). o-Phosphoric acid was incorporated for maintaining the $\mathrm{pH}$ of the mobile phase below the $\mathrm{pK}_{\mathrm{a}}$ value of RFL (8.74). The excitation and emission wavelengths of RFL in the selected mobile phase were determined by the excitation and emission spectra at 290 and $380 \mathrm{~nm}$, respectively (Figure 2).

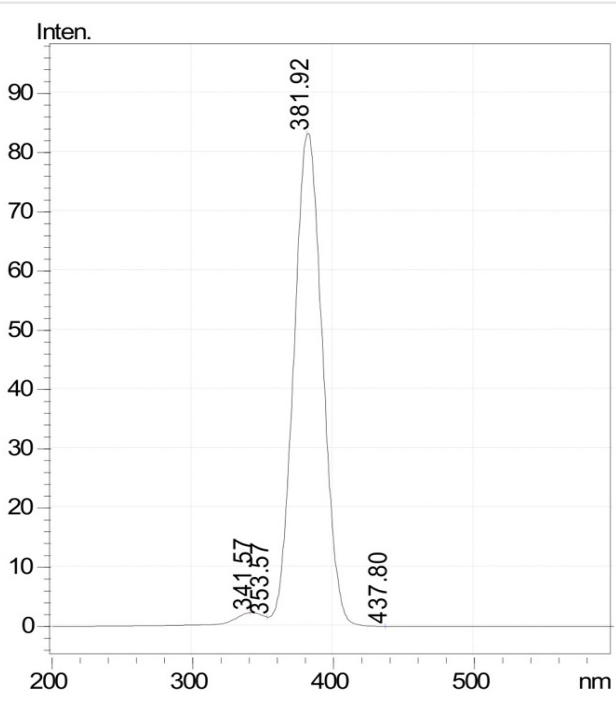

Figure 2. Emission spectrum of roflumilast at excitation wavelength of $290 \mathrm{~nm}$

Table 1. System suitability parameters*

\begin{tabular}{|c|c|c|c|c|c|c|}
\hline Analyte & $t_{R}(\min )$ & Tailing factor (t) & Resolution $\left(R_{s}\right)$ & Capacity factor (k') & $\begin{array}{l}\text { Number of theoretical } \\
\text { plates }(\mathrm{N})\end{array}$ & $\begin{array}{l}\text { Height equivalent of a } \\
\text { theoretical plate (HETP) }\end{array}$ \\
\hline IRB & $4.359 \pm 0.001$ & $1.242 \pm 0.014$ & - & $4.812 \pm 0.001$ & $3,272 \pm 50$ & $45.86 \pm 0.70$ \\
\hline RFL & $5.801 \pm 0.002$ & $1.270 \pm 0.002$ & $4.075 \pm 0.014$ & $6.094 \pm 0.051$ & $3,321 \pm 12$ & $45.17 \pm 0.16$ \\
\hline
\end{tabular}




\section{Validation}

\section{Linearity}

A linear relationship was established in the range of 1.25-10.00 $\mu \mathrm{g} / \mathrm{mL}$ for RFL by a seven-point calibration curve under the optimised HPLC conditions and the calibration chromatograms were shown in Figure 3. Table 2 presents the regression data of RFL.

\section{Limits of Detection and Quantitation (LOD and LOQ)}

LOD and LOQ were calculated as 0.07 and $0.22 \mu \mathrm{g} / \mathrm{mL}$, respectively, using the data presented in Table 2.

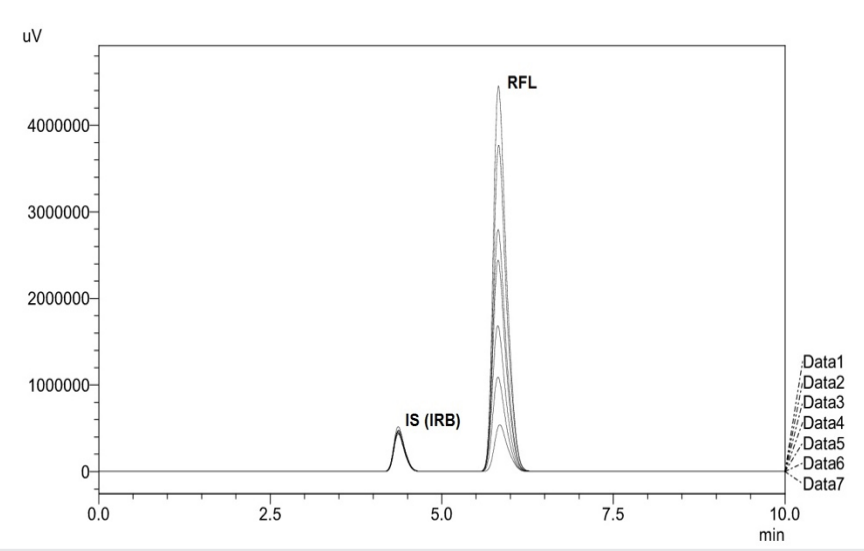

Figure 3. HPLC-FD chromatograms of the calibration standards

HPLC-FD: High-performance liquid chromatography-fluorescence detection

Table 2. Regression analysis results, LOD and LOQ of the proposed method*

Intercept

$-0.2013$

Standard deviation of the intercept

0.0278

Slope

1.2769

Standard deviation of the slope

0.0047

Coefficient of determination (R2)

0.9992

LOD $(\mu \mathrm{g} / \mathrm{mL})$

0.07

LOQ $(\mu \mathrm{g} / \mathrm{mL})$

0.22

*Three replicates/day in three different days, LOD: Limit of detection , LOQ: Limit of quantitation

\section{Precision and Accuracy}

Precision and accuracy were analysed at low, middle and high concentrations with standard solutions. The repeatability and the intermediate precision were calculated in terms of RSD\% (Table 3) and were $\leq 0.96$. The accuracy was examined in terms of $\mathrm{RME} \%$ within a range of -0.58 to $0.84 \%$.

\section{Specificity}

An injection of the mobile phase indicated that the interference effect was not present under the optimised experimental conditions (Figure 4).

\section{Robustness}

The parameters of the flow rate $( \pm 0.1)$, the mobile phase composition and the column temperature $( \pm 1)$ were varied to check the robustness of the method using the tablet solution. The flow rate values of $0.9 \mathrm{~mL} / \mathrm{min}$ and $1.1 \mathrm{~mL} / \mathrm{min}$; the mobile phase compositions of $0.08 \%$ o-phosphoric acid: $\mathrm{MeOH}$ as 19:81 and 21:79 (v:v); and the column temperatures of $39^{\circ} \mathrm{C}$ and $41{ }^{\circ} \mathrm{C}$ were examined (Table 4). The flow rate had the highest impact on the results, and the data were significantly different from the ones obtained by the original HPLC conditions ( $\mathrm{t}$-test at $\mathrm{p}=0.05$ ). The variations in the other analysed parameters exerted insignificant effects according to the statistical analyses (t-test at $\mathrm{p}=0.05)$.

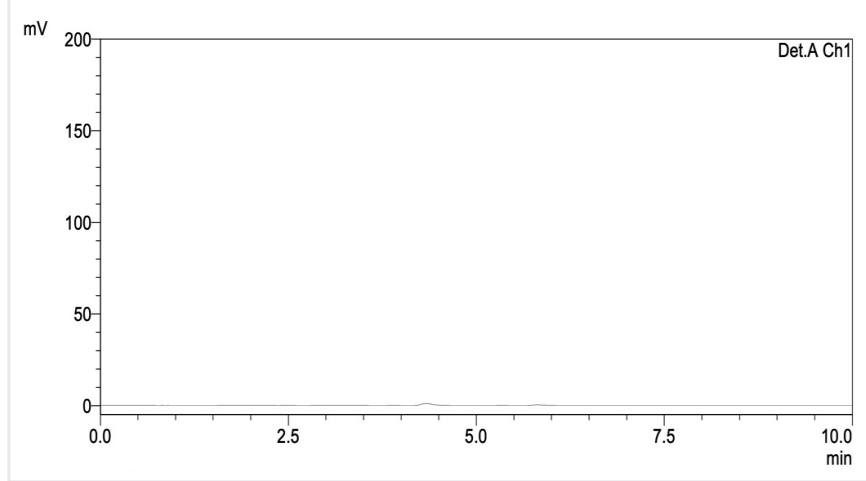

Figure 4. HPLC-FD chromatogram of the mobile phase HPLC-FD: High-performance liquid chromatography-fluorescence detection

Table 3. Repeatability (interday), intermediate precision (intraday) and accuracy of the proposed method

\begin{tabular}{|c|c|c|c|c|}
\hline & Concentration ( $\mu \mathrm{g} / \mathrm{mL})$ & Concentration found $(\mu \mathrm{g} / \mathrm{mL})$ * & $\mathrm{RSD}(\%)^{¥}$ & $\operatorname{RME}(\%)^{\dagger}$ \\
\hline \multirow{3}{*}{ Intraday (n=3) } & 1.25 & $1.25 \pm 0.01$ & 0.71 & -0.22 \\
\hline & 5.00 & $5.04 \pm 0.02$ & 0.38 & 0.84 \\
\hline & 10.00 & $10.06 \pm 0.01$ & 0.14 & 0.61 \\
\hline \multirow{3}{*}{ Interday (n=3) } & 1.25 & $1.24 \pm 0.01$ & 0.96 & -0.58 \\
\hline & 5.00 & $5.03 \pm 0.02$ & 0.49 & 0.61 \\
\hline & 10.00 & $10.05 \pm 0.01$ & 0.10 & 0.54 \\
\hline
\end{tabular}




\section{Analysis of the Tablet Formulation}

The proposed method was applied for quantifying RFL in the tablet formulation of DAXAS ${ }^{\bullet}$ (Figure 5). The original tablet solution and the tablet solutions spiked at 1.00, 2.50 and 5.00 $\mu \mathrm{g} / \mathrm{mL}$ were analysed successfully with high precision and accuracy (Table 5). The RSDs were lower than $2 \%$, and the recovery\% values were between 99.43 and $101.05 \%$.

Because there was not any official monograph for quantifying RFL, the analyses were performed only by the proposed method.

\section{Discussion}

In the proposed work, a new HPLC-FD method was developed and validated for determining RFL in tablets. The validation results were compared with the limitations in the FDA, Reviewer Guidance, Validation of Chromatographic Methods (14). The method provided good system suitability values with $\mathrm{t}<2$, Rs $<2$, $\mathrm{k}^{\prime}>2$ and $\mathrm{N}>2000$. In the tablet analysis, the precision values in terms of RSD\% were lower than 1 (except tablet solution spiked at $2.50 \mu \mathrm{g} / \mathrm{mL}$, interday precision, $1.14 \%$ ) with high recoveries. Selected published studies on the determination of RFL in tablet formulations by HPLC in the literature were compared with the proposed method in Table 6 in terms of retention time, LOD and LOQ $(7,15)$. Unlike this work, the LOD and LOQ were calculated using 3.3 and 10 times of the signal-to-noise ratio in these studies $(7,15)$, but the values could give an idea to examine the results obtained by detection of UV and fluorescence. The linear ranges were different from each other. In the proposed method, it was between $25 \%$ and $200 \%$ of the concentration of the tablet solution. Barhate and Deosthalee determined the linearity range as $10 \%-150 \%$ of the theoretical test concentration of $150 \mu \mathrm{g} / \mathrm{mL}$ (15), whereas Belal et al. (7) investigated the linear range without considering the concentration of the tablet solution or the test solution. In all the compared methods, the $\mathrm{r}^{2}$ values were higher than 0.999 . Also, in those studies, the external standard method was performed for calibration, but an internal standard was used in this study. The proposed method possessed the shortest retention time. The method developed by Belal et al. (7) was a stability-indicating method. Future studies might be

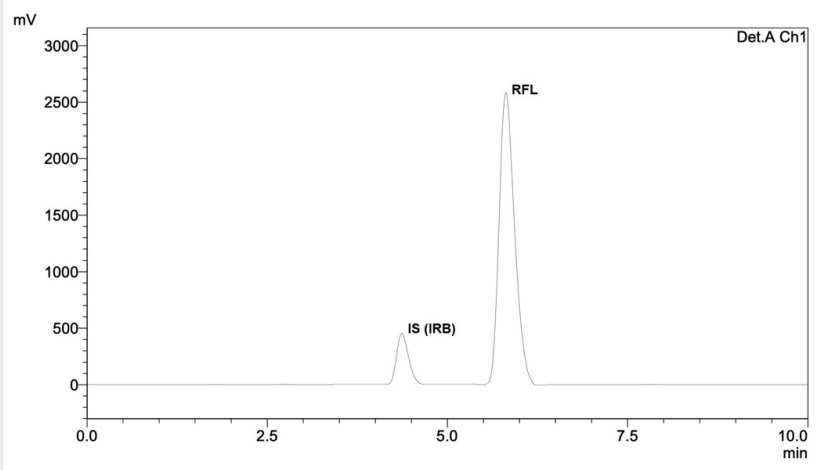

Figure 5. HPLC-FD chromatogram of the tablet solution HPLC-FD: High-performance liquid chromatography-fluorescence detection

Table 4. Robustness of the proposed method*

\begin{tabular}{|c|c|c|c|c|c|}
\hline \multicolumn{2}{|l|}{ Flow rate } & \multicolumn{2}{|l|}{ Composition of mobile phase } & \multicolumn{2}{|c|}{ Column temperature } \\
\hline $0.9 \mathrm{~mL} / \mathrm{min}$ & $1.1 \mathrm{~mL} / \mathrm{min}$ & o-Phosphoric acid 19\%: MeOH 81\% & o-Phosphoric acid 21\%: MeOH 79\% & $39^{\circ} \mathrm{C}$ & $41{ }^{\circ} \mathrm{C}$ \\
\hline $7.23 \pm 0.92$ & $-8.38 \pm 0.25$ & $-0.73 \pm 0.23$ & $-0.76 \pm 0.59$ & $-0.64 \pm 0.15$ & $-1.19 \pm 0.84$ \\
\hline
\end{tabular}

Table 5. Analysis results of the original and spiked tablet solutions

\begin{tabular}{|c|c|c|c|c|c|}
\hline Sample & Concentration ( $\mu \mathrm{g} / \mathrm{mL})$ & Concentration found ( $\mu \mathrm{g} / \mathrm{mL}) *$ & \multicolumn{2}{|l|}{ RSD \% } & Recovery \%* \\
\hline & & & Intraday & Interday* & \\
\hline Original tablet solution & 5.00 & $5.05 \pm 0.01$ & 0.20 & 0.23 & $101.05 \pm 0.23$ \\
\hline Tablet solution spiked at $1.00 \mu \mathrm{g} / \mathrm{mL}$ & 6.00 & $6.05 \pm 0.03$ & 0.09 & 0.54 & $100.78 \pm 0.55$ \\
\hline Tablet solution spiked at $2.50 \mu \mathrm{g} / \mathrm{mL}$ & 7.50 & $7.50 \pm 0.09$ & 0.36 & 1.14 & $100.03 \pm 1.14$ \\
\hline
\end{tabular}

Table 6. Comparison of the proposed method with selected published HPLC methods for determination RFL

\begin{tabular}{|l|l|l|l|l|}
\hline Method & $t_{R}(\mathrm{~min})$ & LOD $(\mu \mathrm{g} / \mathrm{mL})$ & LOQ $(\mu \mathrm{g} / \mathrm{mL})$ & Reference \\
\hline HPLC-DAD & $6.24 \pm 0.005$ & 0.56 & 1.87 & 7 \\
\hline HPLC-UV & 8.64 & 0.02 & 0.065 & 15 \\
\hline Proposed method & $5.801 \pm 0.002$ & 0.07 & 0.22 & \\
\hline
\end{tabular}

HPLC-DAD: High-performance liquid chromatography-diode array detect, HPLC-UV: High-performance liquid chromatography-diode array detect-ultraviolet, RFL: Roflumilast, LOD: Limit of detection, LOQ: Limit of quantitation 
performed to investigate the applicability of the proposed HPLCFD method for indicating the stability of the drug material.

\section{Conclusion}

This study developed and validated a novel HPLC-FD method for determining RFL in tablet formulations. The proposed method has the advantages of simplicity, rapidity and suitable sensitivity. Also, the FD increases the selectivity of the method comparing with the studies performed by HPLC-UV or HPLC$\mathrm{DAD}$. The method was found to be appropriate for the routine analysis of RFL in tablet formulations in terms of reliability and being easy to perform.

\section{Ethics}

Ethics Committee Approval: Ethics committee approval is not required for the study. Analysis was carried out only in tablet formulation.

Peer-review: Externally peer reviewed.

\section{Authorship Contributions}

Concept: P.K.Y., Design: P.K.Y., Analysis or Interpretation: U.M., P.K.Y., Literature Search: U.M., P.K.Y., Writing: P.K.Y.

Conflict of Interest: No conflict of interest was declared by the authors.

Financial Disclosure: The authors declared that this study received no financial support.

\section{References}

1. Jemal A, Ward E, Hao Y, Thun M. Trends in the leading causes of death in the United States, 1970-2002. JAMA 2005;294:1255-9.

2. Pinner NA, Hamilton LA, Hughes A. Roflumilast: a phosphodiesterase- 4 inhibitor for the treatment of severe chronic obstructive pulmonary disease. Clin Ther 2012;34:56-66.

3. Rabe KF, Hurd S, Anzueto A, Barnes PJ, Buist SA, Calverley P, et al. Global strategy for the diagnosis, management, and prevention of chronic obstructive pulmonary disease: GOLD executive summary. Am J Respir Crit Care Med 2007;176:532-55.
4. Bethke TD, Lahu G. High absolute bioavailability of the new oral phosphodiesterase-4 inhibitor roflumilast. Int J Clin Pharmacol Ther 2011;49:51-7.

5. Bethke TD, Böhmer GM, Hermann R, Hauns B, Fux R, Mörike $\mathrm{K}$, et al. Dose-proportional intraindividual single- and repeated-dose pharmacokinetics of roflumilast, an oral, once-daily phosphodiesterase 4 inhibitor. J Clin Pharmacol 2007;47:26-36.

6. Kuchi R. A novel RP-HPLC method for the quantification of roflumilast informulations. The Experiment 2013;7:388-94.

7. Belal TS, Ahmed HM, Mahrous MS, Daabees HG, Baker MM. Validated stability-indicating HPLC-DADmethod for determination of the phosphodiesterase (PDE-4) inhibitor roflumilast. Bull Fac Pharma Cairo Univ 2014;52:79-89.

8. Pinheiro MS, Marins RCEE, Cabral LM, Sousa VP. Development and validation of a RP-HPLC method for Roflumilast and its degradation products, J Liq Chromatogr Relat Technol 2018;41:223-31.

9. Tan F. Development and validation of stability-indicating HPLC method for roflumilast and related substances. Adv Mat Res 2013;781-4:68-71.

10. Suganthi A, Arthi K, Ravi TK. A validated stability-indicating HPTLC method for the determination of roflumilast in tablets and application to accelerated stability studies. Indian J Pharm Sci 2017;79:287-93.

11. Ladani JJ, Bhimani RD, Vyas KB, Nimavat KS. Method development and validation of roflumilast in tablet dosage form by UV spectrophotometry. JAMONLINE 2012;2:369-74.

12. Atmaca M, Süslü İ. Determination of roflumilast inpharmaceutical formulations by derivativespectrophotometric method. Hacettepe Univ J Fac Pharm 2016;1:27-49.

13. Güray T. A new validated method for determination of roflumilast in tablet by CZE-UV. Quim Nova 2019;42:522-6.

14. Food and Drug Administration, Reviewer Guidance, Validation of Chromatographic Methods, November: 1994.

15. Barhate VD, Deosthalee P. Rapid liquid chromatographic method for the determination of roflumilast in the presence of degradation products. Indian J Pharm Sci 2010;72:401-4. 